\title{
Handling Code
}

National Cancer Institute

\section{Source}

National Cancer Institute. Handling Code. NCI Thesaurus. Code C95339.

A coded value that represents a special handling requirement for the labeled material or object. 